\title{
Effects of biguanides on oxidative phosphorylation
}

Judy Hirst

From Metabolism, Diet and Disease 2014: Cancer and metabolism

Washington DC, USA. 28-30 May 2014

Metformin, and the related biguanides buformin and phenformin, have been proposed to act by inhibiting respiratory complex I, causing the cellular energetic stress that activates AMP-kinase and initiates a multitude of cell-lineage-specific effects, including inhibition of gluconeogenesis in hepatocytes. However, the molecular mechanism of biguanide action on complex $I$ is not known, limiting understanding of pharmacological effects on this proposed primary target. Biguanides have also been proposed to affect reactive oxygen species production in cells, a respiratory-chain linked effect - but there is no consensus even on whether they increase or decrease it. In this talk I will discuss the results of experiments on a hierarchy of systems, from purified respiratory enzymes and membrane preparations, to mitochondria and cells, to define the functional effects of biguanides on the oxidative phosphorylation system. The aim is to define and link the molecular effects of biguanides on specific enzymes to their known effects on cellular and signalling pathways.

Published: 28 May 2014

doi:10.1186/2049-3002-2-S1-O28

Cite this article as: Hirst: Effects of biguanides on oxidative

phosphorylation. Cancer \& Metabolism 2014 2(Suppl 1):O28.

MRC Mitochondrial Biology Unit, Cambridge, UK

Submit your next manuscript to BioMed Central and take full advantage of:

- Convenient online submission

- Thorough peer review

- No space constraints or color figure charges

- Immediate publication on acceptance

- Inclusion in PubMed, CAS, Scopus and Google Scholar

- Research which is freely available for redistribution 